\title{
Impact of Intellectual Capital Efficiency on Profitability (A Case Study of LSE25 Companies)
}

\author{
Muhammad Abdul Majid Makki", Suleman Aziz Lodhi"
}

\begin{abstract}
The aim of this study is to examine the relationship between intellectual capital efficiency and the firm's profitability. The importance of intellectual capital (IC) and the related philosophy of the knowledge economy have captured the attention of researchers and business enterprises in the World Trade Organization (WTO) era. IC is widely recognized as a tool that is critical to running a successful business in a highly competitive environment. Various models have been introduced to measure the numerous facets of IC, including the Skandia navigator, Tobin's $Q$, and value added intellectual coefficient (VAIC). This article examines the role of IC efficiency in the firm's net profit using the VAIC developed by Ante Pulic (1998). It also investigates its correlation with the firm's profitability, using regression models.

A five-year data set for Labore Stock Exchange Index companies (LSE-25) was obtained from audited financial reports, and used to calculate human capital, structural capital, and capital-employed efficiency of companies in different industrial sectors. The results obtained using multiple regression analysis supports the argument that IC efficiency contributes significantly to the firm's profitability. Practically, IC efficiency can be used as a benchmark and strategic indicator to direct financial and intellectual resources in the right direction, i.e., to enhance the firm's ultimate corporate value. It can also be developed as a management tool to create a sustainable comparative advantage in the competitive global knowledge economy. The study is a pioneering attempt to measure the impact of IC efficiency on net profit using cross sectional time series data.
\end{abstract}

JEL Classification: C22, C59.

Keywords: Knowledge Economy, Intellectual Capital, Value Added, VAIC, LSE-25.

\footnotetext{
* Lecturer, Department of Commerce, Islamia University of Bahawalpur, Pakistan.

** Associate Professor, National College of Business Administration \& Economics, Lahore, Pakistan.
} 


\section{Introduction}

By the end of the Second World War in 1945, most agriculturebased economies in Europe and North America had transformed into manufacturing economies, changing the focus from land and labor to financial and physical capital. Today, world economies are moving from manufacturing toward knowledge-based economic activity. Drucker (1993) indicates that knowledge is the only meaningful factor of production that is superior to land, labor, and capital. He adds that the unique contribution of management in the $20^{\text {th }}$ century was the 50 -fold increase in the manual worker's productivity through the conversion of 1abor-intensive economies into manufacturing economies. In the $21^{\text {st }}$ century, management has contributed to the increase in productivity of the knowledge worker and a shift from production equipment to knowledge work. This is why many firms and even countries are planning strategies to reposition themselves in the emerging knowledge economy. In the current era of the knowledge economy, business resources comprise $20 \%$ tangible assets and $80 \%$ that are intangible (IT World, 2000). The corporate performance measurement system, however, dates back to the manufacturing era, and is heavily inclined toward financial and physical aspects, lacking relevant information on the performance of intellectual capital (IC). Thus, different ways of monitoring operations are needed to achieve maximum productivity from companies' intangible resources.

Economic managers in many countries feel that the transformation of production-based economies to knowledge-based economies is inevitable if they are to maintain the pace of economic development. For example, Malaysia's Knowledge Economy Master Plan, 2001 devises strategies to transform the country from an input-driven to a knowledge-driven economy. Naquiyuddin and Heong (1992) explain that knowledge is a necessity and can be used as a strategic tool against competitors. According to Pulic (2000), IC is a moving force for business success. The vital role of knowledge is also emphasized in the World Development Report (1998) as "today's most technologically advanced economies are truly knowledge based." Sri Lanka, another developing country, also plans to divert its economy to a knowledge-based economy (Abeysekera, 2007). Currently, the Sri Lankan government is investing heavily to maintain its high literacy level and skilled labor force. This makes it easier for investors to maximize their return on capital (World Bank, 2004).

The Government of Pakistan is trying hard to prepare for the challenges of the knowledge economy in the globalization era. "Vision 2030," an economic master plan, commits to increasing funds for higher 
education, skill development, and science and technology worth up to $1 \%$ of gross national product (GNP). This is expected to increase the proportion of qualified graduates from $4 \%$ to $20 \%$ by 2020 . Amjad (2006) suggests that Pakistan could become more competitive in the global economy after investing in knowledge, technology, and new product development. Kalim and Lodhi (2005) emphasize that Pakistan must take drastic steps toward making its economy and industry more knowledge-intensive, or otherwise stand the risk of losing even its present share of world exports.

In a knowledge economy, IC is considered crucial to the competitiveness of many companies, regardless of which industry they belong to. Johnson and Kaplan (1987) argue that IC could be the most important consideration in the performance of a company. Bornemann (1999) suggests a correlation between intellectual potential and financial performance. It is natural to question why IC should be measured. The logical answer is because IC is an influential intangible strategic asset capable of transforming a national company into a multinational, even transnational corporate powerhouse in an even more competitive knowledge economy. IC measurement and management become very important when service sectors play a vital role in the growth of the global economy, and when their share in gross domestic product (GDP) rises more rapidly than that of the production sector.

The Lahore Stock Exchange (LSE), Pakistan's second largest stock market, is an interesting case for examining the efficiency of IC in the corporate sector. A sample of LSE-25 companies was selected keeping in view that most companies with vast intellectual capital management (ICM) experience are large-scale organizations around the globe are large scale organizations around the world. Comprehensive IC performance data and disclosures are generally provided by large, publicly traded companies in their annual reports. Most investors are inclined to buy shares in LSE-25, which is why more than $90 \%$ of trading at the LSE is done in these companies (LSE Newsletter 2007). Finally, LSE-25 represents a range of industries, making it easier to generalize the findings.

This research focuses on the firm's net profit, asking whether it changes with a change in IC efficiency using the VAIC. This method provides a standardized and straightforward measure of calculating and comparing IC performance across various sectors at national and international levels. The method uses publicly available audited information, which is more reliable and more usable by internal and external stakeholders to check IC efficiency. The VAIC-based view of the firm gives a better insight into viewing a firm's value-creation efficiency using different 
IC resources. Using the VAIC index, this paper examines the association of value addition with traditional measures of profitability i.e., IC and net profit, following Mavridis (2005). The study is quantitative and based on 5year data for 2002 to 2006, gathered from the audited annual reports of LSE-25 companies. These annual reports were gathered through direct contact, databases, LSE resources, and companies' websites. Companies in the sample cover more than five industrial sectors, making the sample representative.

Table-1: Sector-Wise Profile of LSE-25 (2006)

\begin{tabular}{lccc}
\hline \multicolumn{1}{c}{ Sector } & Firms & Years 2002-06 & Firm-Years \\
\hline Banks & 7 & 5 & 35 \\
Oil/Gas/Power & 7 & 5 & 35 \\
Cement & 5 & 5 & 25 \\
Chemicals/Fertilizers & 2 & 5 & 10 \\
Others & 4 & 5 & 20 \\
\hline \multicolumn{1}{c}{ Total } & $\mathbf{2 5}$ & & $\mathbf{1 2 5}$ \\
\hline
\end{tabular}

\section{Literature Review}

There have been many attempts to define the term IC. Generally, IC is defined as the creative abilities of the human brain or mind. Edvinson and Malone (1997) define IC as "knowledge that can be converted into value." They also explain that the difference between market value and book value is the value of IC. Stewart (1997) views IC as knowledge, information, intellectual property, and expertise that can be put to use to create wealth. According to Bontis (2000), IC means individual workers' knowledge and organizational knowledge that together contribute to sustainable competitive advantage. He further elaborates that IC in a broad sense consists of human capital and structural capital. Pulic (2000) includes in IC, all employees' abilities that create value addition. Moore (1996) defines IC as customer capital, innovation capital, and organizational capital. On the other side of the fence are Blair and Wallman (2001) who argue that it is difficult to give a precise definition for intangible assets as well as IC.

There are two schools of thought with regard to the measurement of IC (Mavridis, 2004). The first school focuses on cost and tries to compute IC through the difference between market and book value. The second school of thought is profit or value-oriented and focuses on measuring IC efficiency 
through value addition by human and structural capital. This approach appears to be the more recognized: it has been used by more than 12 researchers from different countries. The VAIC has become very popular due to its straightforward calculations, availability of reliable audited data, and easy comparison across various industrial sectors (Pulic 2004). Alternative IC measures are limited as they only be calculated by internal parties or rely on sophisticated models, analysis, and principles (Pulic 2004). On the other hand, Sveiby (1997) proposes a conceptual framework for IC that is based on external structure (brands, customer and supplier relations); internal structure (organization, structure, system corporate attitude, research and development (R\&D) and procedures); and individual competence (education, experience). He argues that money must not be used as proxy for human efforts.

In relation to reporting IC, Guthrie et al (2006) refer to stakeholders and legitimacy theory. The stakeholders theory provides the right to all stakeholders to obtain information related to organizational activities and its impact on their interests, even if they do not choose to utilize that information or do not have the authority to play a constructive role in the organization (Deegan, 2000). The theory of the stakeholder includes all stakeholders, including potential and current investors, customers, creditors, employees, suppliers, government, and the public (Donaldson and Preston, 1995). The stakeholders theory creates organizational responsibility for the voluntary disclosure of information about intellectual, social, and environmental performance other than statutory requirements to make the disclosure as transparent as possible (Guthrie et al, 2006). In the same way, the legitimacy theory creates a social contract between the firm and the surrounding community in which it operates. From the perspective of this theory, a firm should voluntarily report on all those activities if the management feels that the community expects any specific report (Deegan, 2000). Legitimacy theory is closely tied to the reporting of IC (Guthrie et al, 2006).

In the developed world, the term IC is widely used by the research community. However, very few studies have used emerging economies as a case for evaluating the implications of IC at stock exchange level. Pulic (2000) used VAIC to analyze and measure the performance of FTSE-250 companies under the London Stock Exchange. Kujansivu and Lonnqvist (2007) utilized a subordinate concept of VAIC and intellectual capital efficiency (ICE) to analyze the IC performance of 20,000 companies covering the 11 largest industries of Finland. Other studies that relate to the IC disclosure of FTSE-100 and S\&P-500 companies were conducted by Williams (2001) and Robert (2000), respectively. 
Mavridis (2004), Goh (2005), and Kamath (2007) use VAIC to analyze the performance of Japanese, Malaysian, and Indian banks, respectively, and find significant differences in IC performance. Firer and Williams (2003), using VAIC, indicate that the association between the IC efficiency of value added and profitability, productivity, and market valuation are generally limited and mixed in South Africa. Mavridis (2005) also uses the VAIC and its subordinate concept, the best performance index (BPI), to analyze the performance of the Greek banking sector and focuses on the role of human capital (HC) and physical capital (CA) in value addition.

In recent studies related to the VAIC and the firm's financial performance, Chen et al (2005) examine the relationship between value creation efficiency and market-to-book value ratios, and investigates the impact of IC on the firm's future performance. Shiu (2006) finds a significant positive correlation between the VAIC and profitability and market valuation but a negative correlation with productivity. He uses the ratio of total revenue to total book value of assets as a proxy for productivity. Tan et al (2007) use the VAIC methodology to examine data on 150 listed companies on the Singapore Stock Exchange, and conclude that IC and firm performance are positively related. Tseng and Goo (2005), in an empirical study of Taiwanese manufacturers, visualize a positive relationship between IC and corporate value.

\section{Research Framework}

The framework of this study is depicted below in Figure 1.

\section{Figure 1: Conceptual Model for IC Efficiency and Firm's Profitability}

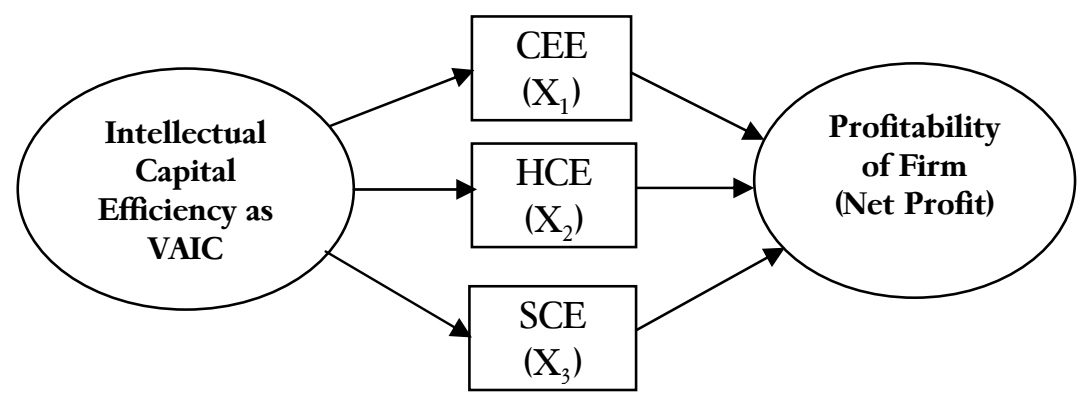

\section{Proxy Measures for Independent and Dependent Variables}

Proxy measures for independent variables identified from the literature review $\left(\mathrm{X}_{1}, \mathrm{X}_{2}, \mathrm{X}_{3}\right)$ are efficiency determinants of VAIC, i.e., CEE, HCE, and SCE; the dependent variable $\left(\mathrm{Y}_{\mathrm{i}}\right)$ is net profit. 


$$
\begin{aligned}
& Y_{\mathrm{i}}=\text { net profit } \\
& \mathrm{X}_{1}=\text { capital employed efficiency (CEE) } \\
& \mathrm{X}_{2}=\text { human capital efficiency (HCE) } \\
& \mathrm{X}_{3}=\text { structural capital efficiency (SCE) } \\
& \varepsilon_{\mathrm{i}}=\text { error term }
\end{aligned}
$$

In this way, the multiple regression model would be:

$$
\mathrm{Y}_{\mathrm{i}}=\beta_{0}+\beta_{1}(\mathrm{CEE})+\beta_{2}(\mathrm{HCE})+\beta_{3}(\mathrm{SCE})+\varepsilon_{\mathrm{i}}
$$

\section{Methodology}

\section{Population and Sources of Data}

The study is based on financial data of the top 25 companies of Lahore stock exchange (volume wise) from 2002-2006, which was collected through direct contact with firms' head offices, databases, Lahore stock exchange and websites of relevant companies. In the beginning it was thought to include all listed companies of Lahore Stock Exchange. But due to constraints in data availability and coverage of $90 \%$ trading of Lahore stock exchange by LSE-25 index companies; the research was reduced to LSE-25. Companies in the case study cover more than five industrial sectors, which increases the representativeness and generalizability of the research outcome within LSE-25 companies.

\section{The VAIC Method}

The VAIC used in this study was introduced by Pulic (1998). It provides a new way of measuring value creation efficiency in companies using data available in financial statements. VAIC is designed to effectively evaluate the efficiency in adding value (VA) to a firm, focusing on value addition in an organization and not on cost control (Pulic 2000). The core concept of the VAIC is that human capital is mainly responsible for a firm's overall performance. The VAIC is based on the following five calculations:

(i) $\quad \mathrm{VA}=$ OUT $-\mathrm{IN}$

where VA is the value addition from current year resources.

Out $=$ total sales and

In $=$ cost of materials, components, and services. 
Alternatively value added can be calculated as:

$\mathrm{VA}=\mathrm{OP}+\mathrm{EC}+\mathrm{D}+\mathrm{A}$

where $\mathrm{OP}=$ operating profit, $\mathrm{EC}=$ employee cost, $\mathrm{D}=$ depreciation, and $\mathrm{A}=$ amortization.

(ii) $\quad \mathrm{CEE}=\mathrm{VA} / \mathrm{CA}$

where CEE is the capital employed efficiency of the firm and

$\mathrm{CA}=$ capital employed (net book value of total assets).

(iii) $\mathrm{HCE}=\mathrm{VA} / \mathrm{HC}$

where HCE is the human capital efficiency of the firm and

$\mathrm{HC}=$ total salaries and wages (direct labor + indirect labor + administration, marketing, and selling salaries).

(iv) $\quad \mathrm{SCE}=\mathrm{ST} / \mathrm{VA}$

where SCE is the structural capital efficiency of the firm and $\mathrm{ST}=\mathrm{VA}-\mathrm{HC}$.

(v) $\quad \mathrm{VAIC}=\mathrm{CEE}+\mathrm{HCE}+\mathrm{SCE}$

where VAIC indicates corporate value creation efficiency.

VAIC does not provide the money value of IC. It simply adds the 3 different efficiency factors of IC and calculates an efficiency index that shows how the IC of a firm contributes to value addition. To measure IC efficiency, Pulic (2000) also offers VAIC's subordinate concept that adds human capital and structural efficiency (ICE $=$ HCE + SCE).

\section{Survey, Description, Analysis, and Results}

The key objective of this study is to examine the role of IC efficiency in firm profitability. Data were collected from five-year audited financial statements of relevant companies. The description of these data aims to better understand the values on the basis of which the IC efficiency of firms and its role in profitability is to be measured. Companies in the sample are not limited to a particular industrial sector, to maximize the extent to which the results can be generalized. 
Table-2: Descriptive Statistics of Selected Variables, 2006

\begin{tabular}{lrrrrr}
\hline \multicolumn{1}{c}{ Variables } & N & Minimum & Maximum & Mean & \multicolumn{1}{c}{ S.D } \\
\hline $\begin{array}{l}\text { Value Added } \\
\text { (Rs. In million) }\end{array}$ & 25 & -39 & 70604 & 12974 & 17511 \\
$\begin{array}{l}\text { Human Capital } \\
\text { (Rs. In million) }\end{array}$ & 25 & 12 & 14700 & 2726 & 3689 \\
$\begin{array}{l}\text { Capital Employed (Rs. } \\
\text { In million) }\end{array}$ & 25 & 4248 & 158840 & 39420 & 37734 \\
$\begin{array}{l}\text { Structural Capital (Rs. } \\
\text { In million) }\end{array}$ & 25 & -5097 & 67384 & 10248 & 15516 \\
Cap. Emp.Efficiency & 25 & -0.0027 & 0.7450 & 0.3081 & 0.2097 \\
Hum. Cap Efficiency & 25 & -3.2221 & 21.9286 & 6.5368 & 5.1534 \\
Structural. Capital & 25 & -0.9591 & 1.3104 & 0.7559 & 0.3847 \\
Efficiency & & & & & \\
$\begin{array}{l}\text { Net Profit } \\
\text { (Rs. In million) }\end{array}$ & 25 & -12763 & 45970 & 5228 & 10733 \\
EPS (Rs.) & 25 & -6.80 & 43.90 & 8.21 & 10.66 \\
ICE & 25 & -1.9117 & 22.8829 & 7.2927 & 5.2865 \\
VAIC & 25 & -1.9144 & 23.6279 & 7.6008 & 5.3994 \\
\hline
\end{tabular}

Table-2 illustrates the mean, minimum, and maximum standard deviation for different dependent and independent variables. The mean of human capital efficiency is 6.5368 with a range from -3.221 to 21.9286 . This means that LSE-25 companies produced Rs.6.54 for every 1 rupee spent on human capital. The average VAIC and ICE remained 7.6008 and 7.2927, respectively.

\section{Regression Assumptions}

The regression assumptions were checked before running the mode1. Although time series data were not used during the study, the Durbin Watson (D-W) test was applied to diagnose first-order autocorrelation problem. D-W values calculated ranged from 1.95 to 2.40 using SPSS. Since the D-W is closer to 2 in all situations, this concludes that the regression model is appropriate, and there is no need to use alternative methods (Neter, 1996). The normality assumption was checked through normal P-P plots extracted through SPSS. The problem 
of high correlation between independent variables was captured in a correlation matrix, which remained between 0.2 and 0.66 for different variables and was treated as acceptable. Tabachnick and Fidell (1996) explain that 0.90 or greater bivariate correlation between independent variables indicates harmful multicollinearity. Tables 4, 5, and 6 depict a variance inflationary factor (VIF) of less than 1.50 in all cases, indicating no multicollinearity. As Snee (1973) suggests, a VIF of less than 5 eliminates the need to search for alternatives to regression. Variances at each level of independent variables were found homogeneous indicating no hetroscedasticity.

Table-3: Multiple Regression Results for the Year 2006

\begin{tabular}{lrrr}
\hline & $\mathrm{Y}_{\mathrm{NP}}=\beta_{0}+\beta_{1}(\mathrm{CEE})+\beta_{2}(\mathrm{HCE})+\beta_{3}(\mathrm{SCE})+\varepsilon_{\mathrm{i}}$ \\
\hline & Beta & St. Error & VIF \\
\hline Intercept & -9621376046 & 3956213351 & \\
$\mathrm{CEE}$ & 26723357490 & 9008583805 & 1.379 \\
$\mathrm{HCE}$ & 452510890 & 377997996 & 1.467 \\
$\mathrm{SCE}$ & 4838810549 & 4406208160 & 1.111 \\
$\mathrm{R}^{2}=0.529$ & Durbin-Watson=1.949 & \\
\hline
\end{tabular}

Table-4: Multiple Regression Results for the Year 2005

\begin{tabular}{lrrr}
\hline \multicolumn{4}{c}{$\mathrm{Y}_{\mathrm{NP}}=\beta_{0}+\beta_{1}(\mathrm{CEE})+\beta_{2}(\mathrm{HCE})+\beta_{3}(\mathrm{SCE})+\varepsilon_{\mathrm{i}}$} \\
\hline Beta & St. Error & VIF \\
\hline Intercept & -8156676513 & 3910926583 & \\
$\mathrm{CEE}$ & 27450441501 & 6637326889 & 1.1646 \\
$\mathrm{HCE}$ & 335317542 & 277332463 & 1.2847 \\
$\mathrm{SCE}$ & 3287077812 & 4500778880 & 1.1118 \\
$\mathrm{R}^{2}=0.573$ & Durbin-Watson $=2.123$ & & \\
\hline
\end{tabular}


Table-5: Multiple Regression Results for the Year 2004

\begin{tabular}{|c|c|c|c|}
\hline \multicolumn{4}{|c|}{$\mathrm{Y}_{\mathrm{NP}}=\beta_{0}+\beta_{1}(\mathrm{CEE})+\beta_{2}(\mathrm{HCE})+\beta_{3}(\mathrm{SCE})+\varepsilon_{\mathrm{i}}$} \\
\hline & Beta & St. Error & VIF \\
\hline Intercept & -2452369741 & 2409412022 & \\
\hline CEE & 22814560265 & 7089702847 & 1.2621 \\
\hline HCE & -39248034 & 326151644 & 1.2818 \\
\hline SCE & -152358381 & 624964195 & 1.1320 \\
\hline $\mathrm{R}^{2}=0.368$ & Vatson $=2.401$ & & \\
\hline
\end{tabular}

Table-6: Multiple Regression Results for the Year 2003

\begin{tabular}{llrl}
\hline & $\mathrm{Y}_{\mathrm{NP}}=\beta_{0}+\beta_{1}(\mathrm{CEE})+\beta_{2}(\mathrm{HCE})+\beta_{3}(\mathrm{SCE})+\varepsilon_{\mathrm{i}}$ \\
\hline & \multicolumn{1}{c}{ Beta } & St. Error & VIF \\
\hline Intercept & -2812040185 & 2940234527 & \\
$\mathrm{CEE}$ & 17004468185 & 5296773588 & 1.201 \\
$\mathrm{HCE}$ & 798554634 & 340739252 & 1.330 \\
$\mathrm{SCE}$ & -3345388214 & 3769097421 & 1.118 \\
$\mathrm{R}^{2}=0.555$ & Durbin-Watson $=2.289$ & & \\
\hline
\end{tabular}

Table-7: Multiple Regression Results for the Year 2002

\begin{tabular}{llcc}
\hline & $\mathrm{Y}_{\mathrm{NP}}=\beta_{0}+\beta_{1}(\mathrm{CEE})+\beta_{2}(\mathrm{HCE})+\beta_{3}(\mathrm{SCE})+\varepsilon_{\mathrm{i}}$ & \\
\hline & \multicolumn{1}{c}{ Beta } & St. Error & VIF \\
\hline Intercept & 4101291808 & 3106846846 & \\
$\mathrm{CEE}$ & 4849441749 & 2972255589 & 1.046 \\
$\mathrm{HCE}$ & 679113516 & 325066500 & 1.092 \\
$\mathrm{SCE}$ & -10527434228 & 3691103901 & 1.068 \\
$\mathrm{R}^{2}=0.424$ & Durbin-Watson $=2.064$ & \\
\hline
\end{tabular}


Tables-3 to 7 present the regression model summaries run for 2006 to 2002. A high coefficient of determination $\left(R^{2}\right)$ in all 5 years shows the strengths of IC in predicting the dependent variable, i.e., the profitability of a firm. The explanatory power of the regression equation over the 5 -year period was $52.9 \%, 57.3 \%, 36.8 \%, 55.5 \%$, and $42.4 \%$, respectively. All three components of the VAIC show positive directional signs in all the years except HCE in 2004 and SCE in 2004, 2003, and 2002. These results show a higher $\mathrm{R}^{2}$ than the study done by Firer and William (2003) who found an explanatory power of $4.8 \%$. Tan et al (2007) found weaker results through multiple regression models with an $\mathrm{R}^{2} 8.7 \%$ and $12.2 \%$ only. The tables also show that CEE has a significantly positive effect on the net profitability of a firm (Significant $\beta$ ) in all the years. The overall results support the argument that all three components of VAIC have a strong impact on the net profit of a firm, suggesting that a firm with greater IC efficiency would fare better in terms of profitability.

\section{Usefulness of the Study}

As a pioneering attempt to analyze the performance of LSE-25 from the perspective of IC, this paper is a good source of reference for future research in the Pakistani corporate sector. The study is based on strong theoretical foundations and research-proven methodology. The data utilized in this study were also prepared by qualified accountants and audited by statutory auditors, thus increasing reliability. Additionally, this study contributes to the existing literature in the following ways:

1. It provides the evidence on the role of IC in profitability of a company using five-year data for different industrial sectors of the LSE. Different components of VAIC show a significant explanatory power for the firm's traditional financial performance. The findings of the study highlight the importance of the role of IC in gaining a competitive advantage in emerging economies.

2. More than $90 \%$ of investors at the LSE and fund and portfolio managers will benefit from the idea of IC modeling as a better measure of evaluating the firm than the traditional approach of net profitability while developing a portfolio. They can observe the impact of IC efficiency not only on annual dividends but also on capital gains. Flostrand (2006), while conducting research on 250 sell-side analysts selected from S\&P-500 companies, finds that analysts use IC indicators frequently in their decision making. 
3. The study proves that VAIC can be used by regulatory authorities to identify the weaknesses and strengths of different industries to help determine which industrial sectors should be subsidized.

\section{Limitations of the Study}

Due to the non availability of non listed and proprietary sector data, this research is limited to LSE-25 index companies. The results of the study cannot, therefore, be generalized to apply to the whole stock market or the non listed sector. Human and structural capital efficiency is not comparable among different sectors within the LSE-25 since different industries are composed of different IC-related factors.

\section{Future Research}

Future study could include extending the IC approach to all the listed companies in Pakistan while focusing on the impact of IC efficiency on future financial performance and total capitalization of companies. Researchers could also concentrate on studying the impact of IC in the intellectual-intensive pharmaceutical sector.

\section{Concluding Remarks}

The study was conducted to examine the relationship between IC and a firm's profitability through empirical research, which has been concluded successfully. The contribution of this research is important both for academic researchers as well as business professionals. IC literature is beneficial in deciding the potential role of IC efficiency in a firm's performance: business professionals benefit by understanding the importance of allocating their precious resources to support IC and ultimately the firm's financial performance. Keeping in view the significant role of IC in financial performance, the study emphasizes the need for guidelines for measuring and disclosing IC in financial reports. As a supervisory body for the corporate sector, the Securities and Exchange Commission of Pakistan and its technical advisors, the Institute of Chartered Accountants of Pakistan and the Institute of Cost and Management Accountants of Pakistan, are urged to take the initiative in this regard. Moreover, as Pakistan opens its stock markets to foreign investors who need financial and nonfinancial information to assist in their decision making, reporting IC becomes all the more important. In a global environment, if information related to IC, health, safety, environment, and corporate social responsibility issues is disclosed in firms' annual reports, it 
could enhance their value in the eyes of international investors. Managers are advised that good structural capital should convert human efficiencies into internal organizational structure, administrative culture, and corporate knowledge. This study is one of the first empirical tests of association between IC and a firm's financial performance in Pakistan, thus proving a good source for IC researchers in the future. 


\section{References}

Abeysekera, I., 2007, "Intellectual Capital Reporting Between Developing and Developed Nation.” Journal of Intellectual Capital, Vo1.8, 2 : 329-345.

Amjad, R., 2006, "Why Pakistan Must Break-Into the Knowledge Economy.” Paper presented at the Second Annual Conference on Management of the Pakistan Economy in Lahore School of Economics, Proceedings published Special Edition of Labore Journal of Economics : 75-87.

Blair, M.M. and Wallman, S.M.H., 2001, Unseen Wealth: Report of the Brooking's Task Force on Intangibles. Brookings Institute Press, Washington, D.C.

Bontis, N., 1998, "Intellectual Capital: An Exploratory Study that Develops Measures and Models.” Management Decisions, Vo1. 36 $2: 63-76$.

Bontis, N., Kew, W.C.C. and Richardson, S., 2000, "Intellectual Capital and Business Performance in Malaysian Industries.” Journal of Intellectual Capital, Vol. 1, $1: 85-100$.

Bornemann, M., 1999, "Potential of Value Systems According to the VAIC Method.” International Journal Technology Management, Vo1. 18 : 463-475.

Chen, M., Cheng, S., Hwang, Y., 2005, “An Empirical Investigation of the Relationship between Intellectual Capital \& Firm's Market Value and Financial Performance.” Journal of Intellectual Capital, Vo1. 6, 2 : 159-176.

Deegan, C., 2000, Financial Accounting Theory. McGraw-Hill Book Corporation, Sydney.

Donaldson, T. and Preston, L.E., 1995, "The Stakeholder Theory of the Corporation: Concepts, Evidence and Implications." The Academy of Management Review, Vo1. 20, 1 : 65-91.

Drucker, P. F., 1993, Post Capitalist Society. Butterworth Heinemann Publishings, Oxford. 
Edvinson, L. and Malone, M., 1997, "Intellectual Capital: Realizing Your Company's True Value by Finding its Hidden Bran Power.” Harper Business, New York.

Firer, S. and William, S.M., 2003, "Intellectual Capital and Traditional Measures of Corporate Performance.” Journal of Intellectual Capital, Vol. $4,3: 348-360$.

Flostrand, P., 2006, "The Sell Side - Observations on Intellectual Capital Indicators.” Journal of Intellectual Capital, Vo1. 7, 4 : 457-473.

Goh, P.C., 2005, "Intellectual Capital Performance of Commercial Banks in Malaysia”, Journal of Intellectual Capital, Vo1.6, 3 : 385-396.

Government of Pakistan, Vision 2030, Planning Commission. Available at: www.pakistan.gov.pk/ministries/planning and developmentministry/vision 2030.htm.

Guthrie, J., Petty, R., Ricceri, F., 2005, "The Voluntary Reporting of Intellectual Capital.” Journal of Intellectual Capital, Vo1. 7, 2 : 254271.

IT World, 2000, Editorial Article, Available at: www.itworld.com?Mag/2698/CIO0103151ev/

Johnson, H. T., Kaplan, R. S., 1987, Relevance Lost: The Rise and Fall of Management Accounting. Harvard Business School Press, Boston.

Kalim R and Lodhi, S. A., 2005, “The Knowledge Based Economy: Trends and Implications for Pakistan.” Pakistan Development Review, Vol. 41,4 (II) : 787-804.

Kamath, G.B., 2007, "The Intellectual Capital Performance of Indian Banking Sector.” Journal of Intellectual Capital, Vo1. 8, 1 : 96-123.

Kujansivu, P., 2007, "Investigating the Value and Efficiency of Intellectual Capita1.” Journal of Intellectual Capital, Vo1. 8, 2 : 272-287.

LSE Newsletter, 2007, Lahore Stock Exchange Guarantee Limited. February Issue.

Mavridis, D.G, 2005, "Intellectual Capital Performance Drivers in the Greek Banking Sector.” Management Research News, Vo1. 28, 5 : 43-62. 
Mavridis, D.G., 2004, The Intellectual Capital Performance of Japanese Banking Sector.” Journal of Intellectual Capital, Vol. 5, 1 : 92-114.

Moore, N.G., 1996, "Measuring Corporate IQ." Chief Executive, November Issue.

Naquiyuddin, T.N.C.P. and Heong, L.H., 1992, Malaysian Entrepreneurs. Malaysian Institute of Management, Kuala Lumpur.

Neter, J., Kutner, M.H., Nachtsheim, C.J. and Wasserman, W., 1996, Applied Statistical Models. $4^{\text {th }}$ Ed. Irwin Publishers, Homewood, IL.

Pulic, A., 1998, "Measuring the Performance of Intellectual Potential in Knowledge Economy.” Available at: www.vaic-on.net

Pulic, A., 2000, "VAIC- an Accounting Tool for IC Management." Available at: www.vaic-on.net

Pulic, A., 2002, "National Intellectual Capital Efficiency Report of Croatian Economy." Available at: www.vaic-on.net (accessed on $7^{\text {th }}$ March 2007).

Pulic, A., 2004, "Intellectual Capital - Does it Create or Destroy Value?" Measuring Business Excellence, Vo1. 8, 1 : 62-68.

Robert, E., 2000, “Corporate Disclosure in the Internet Age.” The Financial Times, $14^{\text {th }}$ May.

Shiu, H., 2006, "The Application of the Value Added Intellectual Coefficient to Measure Corporate Performance: Evidence from Technological Firms.” International Journal of Management, Vo1. $23,2: 356-365$.

Snee, R.D., 1973, "Some Aspects of Non Orthogonal Data Analysis: Developing Prediction Equations." Part I, Journal of Quality Technology, Vo1. 5 : 67-79.

Stewart, T.A., 1997, Intellectual Capital: The New Wealth of Organizations. Doubleday, New York, N.Y.

Sveiby, K.E., 1997, The New Organizational Wealth: Managing and Measuring Knowledge based Assets. Barrett-Kohler Publishers, San Francisco. 
Tabachnick, B.G. and Fidell, LS., 1996, Using Multiple Statistics. Harper Collins Publishers, New York, NY.

Tan, H.P., Plowman, D., Hancock, P., 2007, "Intellectual Capital and Financial Returns of Companies." Journal of Intellectual Capital, Vol. 8, 1 : 76-94.

Tseng, C., Goo, Y.J., 2005, "Intellectual Capital and Corporate Value in an Emerging Economy: Empirical Studies of Taiwanese Manufacturers”. $R \& D$ Management, Vo1. 35, $2: 187-201$.

William, S.M., 2001, Is a Company's Intellectual Capital Performance and Intellectual Capital Disclosure Practices Related? Evidence from Publicly Traded Companies from FTSE-100", available at: www.vaicon.net (accessed on $16^{\text {th }}$ March, 2007).

World Bank, 1998, World Development Report. Available at: www.worldbank.org.

World Bank, 2004, Sri Lanka Development Policy Review. December Issue, World Bank Colombo Office, Colombo. 